The Crown and the Courts 



\section{The Crown and the Courts}

SEPARATION of POWERS

in the EARLY JEWISH IMAGINATION

\section{David C. Flatto}

Harvard University Press

CAMBRIDGE, MASSACHUSETTS

LONDON, ENGLAND

2020 
Copyright (C) 2020 by the President and Fellows of Harvard College All rights reserved

Printed in the United States of America

Publication of this book has been supported through the generous provisions of the Maurice and Lula Bradley Smith Memorial Fund

First printing

Cover design: Tim Jones

9780674249585 (EPUB)

9780674249592 (MOBI)

9780674249608 (PDF)

Cataloging-in-Publication Data is available from the Library of Congress

ISBN: 978-o-674-737I0-5 (alk. paper) 
To the beloved memory of my mother, Dr. Zehava Flatto z'1 And in honor of my father, Dr. Leopold Flatto 
